УАK 347.9:354

ББК $67.410+66.3(0), 123$

DOI 10.22394/1682-2358-2017-3-66-72

E.A. Belousova, post-graduate student of the Arbitration Process Department, Saratov State Academy of Law

\section{CONCILIATORY \\ PROCEDURES \\ IN PROTECTION \\ OF PUBLIC \\ INTERESTS BY PUBLIC \\ AUTHORITIES \\ AND LOCAL GOVERNMENT BODIES}

Possibilities of conclusion of a settlement agreement on matters related to protection of public interests by public authorities and local government is considered. The author formulates conditions under which it becomes possible to conclude settlement agreements in such cases.

Key words and word-combinations: public interest, protection, settlement agreement, conditions.
Е.А. Белоусова, аспирант кафедры арбитражного прочесса Саратовской государственной торидиеской академи (email: arxangel2703@ mail.ru)

\section{ПРИМИРИТЕАЫНЫЕ}

ПРОЦЕАУРЫ В ЗАЩИТЕ ПУБАИЧНО-ПРАВОВЫХ ИНТЕРЕСОВ ГОСУААРСТВЕННЫМИ ОРГАНАМИ И ОРГАНАМИ МЕСТНОГО САМОУПРАВАЕНИЯ

Аннотация. Рассматривается возможность заключения мирового соглашения по делам, связанным с защитой публичных интересов органами государственной власти и местного самоуправления. Автором формулируются условия, при которых становится возможным заключение мировых соглашений по таким категориям дел.

Ключевые слова и словосочетания: публичный интерес, защита, мировое соглашение, условия.

егодня в мировой практике независимо от того, какой суА, общей ими спещиамьной юрисаикции, рассматривает экономические споры, существует явная тенденщия к развитию примирительных проџедур и созданию системы амьтернативных органов, упомномоченных разрешать сулебные споры. Согласно общей норме, изложенной в ст. 138 АПК РФ, арбитражный суА принимает меры Аля примирения сторон, содействует им в урегумировании спора. 
Среди проџедур, направленных на разрешение дела и предусмотренных АПК РФ, кроме мирового соглашения, слеАует отметить права органа власти как процессуального истца: на отказ от иска, предусмотренный ч. 2 ст. 49; на признание иска, установленного ч. 3 ст. 49; на признание фактических обстоятельств дела и заключение соглашения о признании обстоятельств дела в соответствии со ст. 70. При этом указанные примирительные процеАуры применимы не только в исковом производстве, но и производстве, возникающем из публичных правоотношений.

Реализация этих проџедур с участием органов власти, обратившихся в зашиту публичных интересов, на практике носит ограничительный характер. Отказ от иска, признание иска мибо признание фактических обстоятельств дела и закмючение соглашения о признании обстоятельств дела, хотя и допустимо, но может противоречить природе требований в защиту публичных интересов. Тем более такие действия могут таить в себе коррупџионные составляющие. Соответствуюшие полномочия Аолжны быть подтверждены в доверенности преАставителя.

Отметим, что закон в случае отказа органов власти от предъявленного иска не мишает истца права требовать рассмотрения дела по существу. ОАнако миџа, имеющие материальный интерес в споре о защите публичных интересов, не имеют прямо предусмотренную законом возможность возражать и оспаривать действия органа власти, предусмотренные ст. 70 АПК РФ. Поэтому полагаем, что признание фактических обстоятельств дела и заключение соглашения о признании обстоятельств в деме о защите пубцичных интересов в порядке, предусмотренном ст. 53 АПК РФ, Аопустимо только в тех случаях, когда судом установлено, что признание фактических обстоятельств соответствует самим обстоятельствам, не явцяется зцоупотреблением со стороны участников дела своими процессуальными правами, не повлечет нарушения прав третьих Аиц.

В отношении допустимости мирового соглашения по делам с участием органов власти в научной митературе сформированы различные позиции. Например, Е.Н. Пименова отмечает, что мировое соглашение не домжно противоречить сути производства, вытекающего из административных и иных пубцичных отношений только в том случае, если материальное законодательство в публичной сфере допускает установление прав и обязанностей сторон по воле участников правоотношения. Кроме того, допустимость мирового соглашения, по ее мнению, обусловлена наличием полного соответствия императивным преАписаниям закона, когда такое соглашение не изменяет существующего между сторонами правоотношения, а мишь констатирует его бесспорность $[1$, c. 20]

Отказ от допустимости мирового соглашения, заключаемого органами власти, как отмечает Е.В. Храмова, свидетельствует о явной дискриминационности такого подхода. Следует согласиться с тем, что понятие «мировое соглашение» носит деперсонифицированный характер, так как применимо как к частноправовым спорам, так и к спорам, возникающим из публичных правоотношений, ввиду чего нет необходимости во введении понятий, раз- 
граничивающих «мировое соглашение» по гражданско-правовым спорам и «соглашение» по публично-правовым, а, наоборот, в цемях устранения юриАической казуистики следует использовать еАиный термин «мировое соглашение» [2, с. 24].

Однако данные обстоятельства затрагивают только производство, вытекающее из административных и иных публичных отношений. Считаем, что вопрос о Аопустимости заключения мирового соглашения по делу с участием органа власти, заявляющего требования в порядке ст. 53 АПК РФ, шире административного производства и подмежит рассмотрению в целом в рамках арбитражного судопроизводства, так как пубцичные интересы могут быть предметом защиты в исковом производстве, производстве, возникающем из пубцичных правоотношений, а также производстве по отАельным категориям Аел, включая особое производство, производство по делам о несостоятельности (банкротстве).

В научной митературе отмечается, что «понятие «мировое соглашение» носит универсальный характер, так как оно применимо как к частноправовым спорам, так и к спорам, возникающим из пубцичных правоотношений». Т.А. Григорьева и Е.В. Храмова отмечают: «Аیя споров, возникающих из пубцичных правоотношений, мировым соглашением будет явцяться мюбое соглашение, согласно которому стороны на взаимовыгодных условиях в пре-

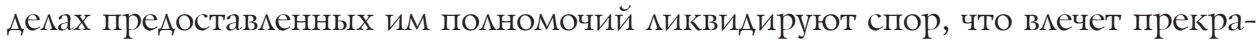
щение производства по Аелу» [3, с. 19] .

Именно поэтому проблематика заключения мирового соглашения органами государственной власти и органами местного самоуправцения несет в себе вопросы допустимости такого соглашения, его условия с точки зрения защиты публичных интересов в зависимости от вида производства. Так, согласно ч. 2 ст. 139 АПК РФ мировое соглашение может быть заключено по мюбому делу, если иное не предусмотрено АПК РФ и иным федеральным законом. Миро-

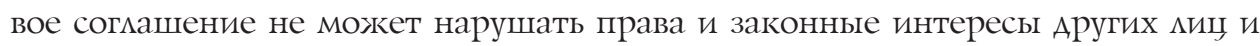
противоречить закону, что установцено в ч. 3 указанной статьи.

Общие условия Аопустимости мирового соглашения с точки зрения прав

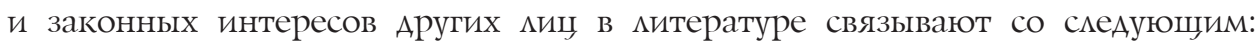
«Поскольку предметом мирового соглашения является распоряжение правами в рамках конкретного материального правоотношения, то стороны могут распорядиться только тем, что им принадлежит. Если же условиями миро-

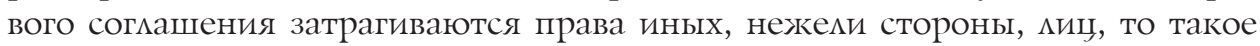
мировое соглашение не может быть утверждено судом, поскольку стороны выходят за рамки своих полномочий и решают вопрос о правах и обязан-

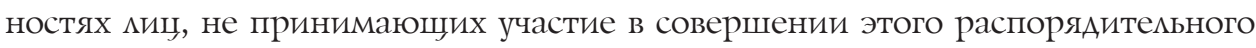
Аействия» [4].

На наш взгляд, такое толкование исключает возможность заключения мирового соглашения по Аелам, связанным с защитой публичных интересов органами государственной вцасти и органами местного самоуправления. Аанная позиция, по нашему представцению, явцяется неверной, так как орган вцасти, участвуя в арбитражном споре по делу о защите пубцичных интересов, уже 
наделен полномочиями по представительству широкого круга интересов. В связи с этим арбитражным судом Аолжна быть Аана Аополнительная оценка мирового соглашения на предмет того, направцено $\Lambda и$ оно на защиту пубцичных интересов, устранен $и$ факт их нарушения, который послужиц оАним из оснований обращений органа вцасти в порядке, преАусмотренном ст. 53 АПК РФ.

Кроме того, полагаем допустимым применение правила, определенного в практике Высшего Арбитражного Суда Российской Федерации, изложенного в п. 17 постановления Пценума указанного суда от 9 декабря 2002 г. № 11 «О некоторых вопросах, связанных с введением в действие Арбитражного проџессуального кодекса Российской Федерации». Аанный пункт связан с сущностью экономических споров, возникающих из административных и иных публичных правоотношений, где отмечено следующее: «Согласно ст. 190 АПК РФ экономические споры, возникающие из административных и иных пубцичных правоотношений, могут быть урегулированы сторонами по правилам, установленным в главе 15 АПК РФ, путем заключения соглашения или с использованием других примирительных проџеАур, если иное не установлено федеральным законом» [5] .

Вместе с тем представляется целесообразным предусмотреть возможность закцючения мировых соглашений по делам, связанным с защитой публичных интересов, на основаниях, предусмотренных нормами материацьного права. По мнению Т.А. Григорьевой и Е.В. Храмовой, «такая регламентация необходима в тех отраслях права, под регулирующее воздействие которых подпадает право, с которым связано мировое соглашение, приводя в качестве примера отрасль налогового права и главный его регуцятор - НК РФ» $[3$, c. 22].

Отдельные особенности, связанные с заключением мирового соглашения по спорам, затрагивающим пубцичные интересы, отмечены в постановлении Пиенума Высшего Арбитражного Суда Российской Федерации от 18 июля 2014 г. № 50: «Мировые соглашения могут заключаться органом, осуществляющим публичные полномочия, по делам об оспаривании его ненормативных правовых актов, решений и действий (бездействия), по делам о взыскании обязательных платежей и санкций» [6] .

В то же время, признавая Аопустимость мирового соглашения по указанным категориям дел, судебная практика не признает правомерности мирового соглашения по демам об административных правонарушениях. К.О. Тотьев полагает: «По смыслу содержащейся в главе 15 АПК РФ ч. 2 ст. 138 предметом мирового соглашения выступает спор сторон исходного правоотношения, который они могут урегулировать с помощью такого соглашения, а не фактическое и юридическое прекращение или предотвращение спора. Иными словами, предметом мирового соглашения служат основанные на противоречии интересов отношения межАу сторонами, которые изменяются ици устраняются с помощью мирового соглашения. Их не следует смешивать со спорными (исходными) ици возникающими на основе мирового соглашения правоотношениями. Такая трактовка 
предмета мирового соглашения отличается от принятого в гражданском законодательстве понимания предмета (объекта) договора, хотя п. 9 постановиения Пиенума Высшего Арбитражного Суда Российской Федераџии от 18 июля 2014 года № 50 и провозглашает подчиненность мирового соглашения общим нормам гражданского права о договорах. Аействительно, в гражданском законодательстве и доктрине предмет договора определяется в зависимости от цели (типа или вида) договора и сводится к имуществу, Аействию ими бездействию» [7] .

В отношении искового производства процессуальное законодательство не устанавливает прямых запретов на заключение мирового соглашения по демам, связанным с защитой публичных интересов органами вцасти, за искцючением ограничений, указанных для всех категорий дел. Так, мировое соглашение может быть заключено по мюбому делу, если иное не предусмотрено АПК РФ и иным федеральным законом, оно не может нарушать права и законные интересы Аругих киџ и противоречить закону.

Полагаем, что на рассмотрение дел по обращениям органов власти в защиту пубцичных интересов может распространяться положение постановцения Пиенума Высшего Арбитражного Суда Российской Федераџии от 23 марта 2012 г. № 15 «О некоторых вопросах участия прокурора в арбитражном процессе» о том, что дело, производство по которому возбуждено на основании заявления прокурора, может быть окончено закмючением мирового согла-

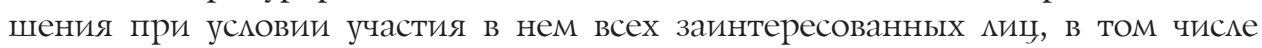
прокурора.

Учитывая специфику ст. 53 АПК РФ, полагаем, что мировое соглашение по делу, связанному с защитой публичных интересов, Аопустимо, если федеральный закон, уполномочивающий орган власти на обращение за защитой публичных интересов, не искмючает заключение мирового соглашения, и если заключение мирового соглашения приведет к устранению нарушений публичных интересов, послуживших предпосылкой Амя обращения в арбитражнный суд на основании п. 3 ст. 53 АПК РФ. ПреАставцяется, что мировое соглашение в Аанном случае может подтверждать императивно установценные права и обязанности, связанные с обеспечением публичных интересов.

Рассмотрим особенности примирительных процедур по делам о защите публичных интересов на основании обращения органов государственной или муниципальной власти в рамках рассмотрения арбитражными судами дел о несостоятельности (банкротстве). В соответствии со ст. 225 АПК РФ «По Аелам о несостоятельности (банкротстве) может быть заключено мировое соглашение в соответствии с федеральным законом, а также Аопускаются иные примирительные проџедуры, предусмотренные главой 15 АПК РФ и Аругими федеральными законами, регулирующими вопросы несостоятельности (банкротства)» [8].

Статья 150 указанного Закона предусматривает возможность заключения мирового соглашения должником, его конкурсными кредиторами и уполномоченными органами на мюбой стадии рассмотрения арбитражным судом 
дела о банкротстве. При этом мировое соглашение вступает в силу для всех миц, участвуюших в мировом соглашении, с даты его утверждения арбитражным судом и явцяется Аля них обязательным [9, с. 4190].

Законом опредемены особенности участия уполномоченного органа, выступающего в защиту публичных интересов, которые выражаются в необходимости получения согласия уполномоченного органа на включение в текст мирового соглашения положения о прекрашении обязательств должника путем предоставления отступного, обмена требований на доли в уставном капитале домжника, акщии, конвертируемые в акции облигации или иные ценные бумаги, новации обязательства, прощения долга или иными предусмотренными федеральным законом способами, а также положения об изменении сроков и порядка уплаты обязательных платежей, включенных в реестр требований кредиторов. При этом такое мировое соглашение не Аолжно нарушать права иных кредиторов, требования которых включены в реестр требований кредиторов [9] .

В качестве выводов отметим, что применительно к защите публичных интересов органами вАасти в арбитражных судах наиболее допустимой примирительной проџедурой явмяется заключение мирового соглашения как проџеАура, позволяюшая с наибольшей точностью соблюсти баланс интересов. При заключении мирового соглашения по делам, связанным с защитой публичных интересов органами государственной власти и органами местного самоуправмения в порядке, предусмотренном ст. 53 АПК РФ, необходимо соблюдение ряда условий. Во-первых, заключение мирового соглашения не домжно противоречить федеральному закону. Во-вторых, закмючение мирового соглашения допустимо, если устранено нарушение пубцичных интересов, указанное в обращении органа власти. В-третьих, мировое соглашение не может нарушать права и законные интересы других миџ.

Анализируя эти условия в совокупности, полагаем, что заключение мирового соглашения по делам, связанным с зашитой публичных интересов органами власти в порядке, установленном ст. 53 АПК РФ, не должно причинять вреА публичным отношениям, и органы, заключающие такое соглашение, не Аолжны выходить за пределы своих полномочий.

В качестве результата исследования предлагается дополнить содержание ст. 53 АПК РФ Аопустимостью мирового соглашения по делам, связанным с защитой публичных интересов, на следующих условиях: если заключение мирового соглашения не противоречит АПК РФ и федеральному закону; если устранено нарушение публичных интересов, указанное в обрашении органа власти; если мировое соглашение не нарушает прав и законных интересов Аругих Аиџ.

\section{Библиографический список}

1. Пименова Е.Н. Проблема соотношения частных и публичных интересов в российском арбитражном процессуальном праве: автореф. дис. ... канд. юрид. наук. Саратов, 2010.

2. Храмова Е.В. Защита публично-правовых интересов в арбитражном процессе (вопросы теории и практики): автореф. дис. ... канд. юрид. наук. Саратов, 2011. 
3. Григорьева Т.А., Храмова Е.В. Мировое соглашение по спорам, затрагивающим публично-правовые интересы: современные проблемы // Законы России: опыт, анализ, практика. 2011. № 8 .

4. Комментарий к Арбитражному процессуальному кодексу Российской Федерации (постатейный) / под ред. В.В. Яркова. М., 2011 [Электронный ресурс]. Доступ из СПС «Гарант».

5. О некоторых вопросах, связанных с введением в действие Арбитражного процессуального кодекса Российской Федерации: постановление Пленума Высшего Арбитражного Суда Российской Федерации от 9 дек. 2002 г. № 11 [Электронный ресурс]. Доступ из СПС «Гарант».

6. О примирении сторон в арбитражном процессе: постановление Пленума Высшего Арбитражного Суда Российской Федерации от 18 июля 2014 г. № 50 [Электронный ресурс]. Доступ из СПС «Гарант».

7. Тотьев К.О. Содержание мирового соглашения с участием антимонопольного органа // Законы России: опыт, анализ, практика. 2015. № 2 [Электронный ресурс]. Доступ из СПС «Гарант».

8. Арбитражный процессуальный кодекс Российской Федерации от 24 июля 2002 г. № 95-Ф3 (в ред. от 1 мая 2016 г.) // С3 РФ. 2002. № 30.

9. О несостоятельности (банкротстве): Федер. закон от 26 окт. 2002 г. № 127-ФЗ (в ред. от 29 дек. 2015) // СЗ РФ. 2002. № 43.

72 Bulletin of the Volga Region Institute of Administration • 2017. Vol. 17. № 3 